\title{
Preparation and Comparative Evaluation of Physicochemical Properties of Microcrystalline Cellulose Derived from Saccharum officinarum $L$ (Poaceae) with Avicel(R) PH102
}

 \\ Bamigbola $^{3}$, Nicholas Edebi Vaikosen ${ }^{4}$, Biobarakuma Aberenimi Joseph ${ }^{5}$ \\ ${ }^{1 *}$ Niger Delta University, Department of Pharmaceutics and Pharmaceutical Technology, Wilberforce Island \\ Amassoma, Nigeria, (ORCID: 0000-0001-8629-7690),judeoraeluno@gmail.com \\ ${ }^{2}$ Nnamdi Azikiwe University, Departmant of Pharmaceutics and Pharmaceutical Technology, Awka, Nigeria, \\ (ORCID: 0000-0000-0000-0000) jc.obasi@unizik.edu.ng \\ ${ }^{3}$ Niger Delta University, Department of Pharmaceutics and Pharmaceutical Technology, Wilberforce Island \\ Amassoma, Nigeria, (ORCID: 0000-0002-0686-8906), bamigbolae@yahoo.com \\ ${ }^{4}$ Niger Delta University, Departmant of Pharmaceutical and Medicinal Chemistry, Wilberforce Island \\ Amassoma, Nigeria, (ORCID: 0000-0002-2413-6127), edebi.vaikosen@ndu.edu.ng \\ 5 Niger Delta University, Department of Pharmaceutics and Pharmaceutical Technology, Wilberforce Island \\ Amassoma, Nigeria, (ORCID: 0000-0000-0000-0000), biojoe1218@yahoo.com
}

(Received date: 03.11.2021 and Accepted date: 08.03.2022)

(DOI: 10.29228/JCHAR.54066)

Corresponding Author: J.N. Oraeluno, Niger Delta University, Department of Pharmaceutics and Pharmaceutical Technology, Wilberforce Island Amassoma, Nigeria, judeoraeluno@gmail.com

CITE : J.N. Oraeluno, J.C. Obasi, E.A. Bamigbola, N.E. Vaikosen, B.A. Joseph, "Preparation and Comparative Evaluation of Physicochemical Properties of Microcrystalline Cellulose Derived from Saccharum officinarum L (Poaceae) with Avicel(R) PH102" J Characterization, vol. 2, no. 1, pp 60-68, March, 2022,

doi:10.29228/JCHAR.54066

\begin{abstract}
This study was aimed at preparation and comparison of the physiochemical properties of a locally prepared microcrystalline cellulose obtained from dried stem pulp chips of sugarcane (Saccharum officinarum) coded SOMCC and compared with a commercial grade (Avicel PH 102). SO-MCC was prepared from -cellulose derived by alkaline hydrolysis from dried sugarcane stem chips, bleached with sodium hypochlorite and treated with $2.5 \mathrm{~N}$ hydrochloric acid. The MCC were identified by BP (2009) method. The comparative physicochemical properties evaluated include: DSC, $\mathrm{pH}$, mean particles diameter, true, bulk and tapped densities, angle of repose, Hausner's quotient, compressibility index, porosity, hydration, swelling and moisture sorption capacities. The results obtained from these tests are: $\mathrm{pH}$ (7.5), mean particle diameter (239), true, bulk and tapped densities (1.54, 0.464, 0.617), angle of repose (34.70), Hausner's quotient (1.32), C.I (25.00), porosity (70.00), hydration, swelling and moisture sorption capacities $(4.00,47.16,21.30)$. The DSC showed a sharp peak at $730 \mathrm{C}$ which depicts high purity. Both MCCs showed the same organoleptic properties, similar DSC and also had poor flowability. Overall, the results indicated that SO-MCC compared favourably with commercial grade Avicel PH 102 in terms of its physicochemical properties and complied with British Pharmacopoeia specifications for microcrystalline cellulose.
\end{abstract}

Keywords: Saccharum officinarum, microcrystalline cellulose, physicochemical properties, Avicel PH 102. 


\section{Fizikokimyasal Özelliklerinin Avicel® PH102 ile Hazırlanması ve Karşılaştırmalı Değerlendirilmesi}

\section{Öz}

Bu çalışmanın amacı, SO-MCC kodlu şeker kamışının (Saccharum officinarum) kurutulmuş kök küspesinden elde edilen yerel olarak hazırlanmış bir mikrokristalin selülozun hazırlanması ve fizikokimyasal özelliklerinin ticari kalite (Avicel PH 102) ile karşılaştırılmasıdır. SO-MCC, kurutulmuş şeker kamışı sapı yongalarından alkali hidroliz yoluyla türetilen, sodyum hipoklorit ile ağartılmış ve $2.5 \mathrm{~N}$ hidroklorik asit ile muamele edilmiş selülozdan hazırlanmıştır. MCC, BP (2009) yöntemiyle tanımlandı. Değerlendirilen karşılaştırmalı fizikokimyasal özellikler şunları içerir: DSC, pH, ortalama partikül çapı, gerçek, yığın ve kademeli yoğunluklar, durma açıSı, Hausner bölümü, sıkıştırılabilirlik indeksi, gözeneklilik, hidrasyon, şişme ve nem emme kapasiteleri. Bu testlerden elde edilen sonuçlar: pH (7.5), ortalama parçacık çapı (239), gerçek, yığın ve kılavuzlu yoğunluklar (1.54, 0.464, 0.617), durma açısı (34.70), Hausner bölümü (1.32), CI (25.00) ), gözeneklilik (70.00), hidratasyon, şişme ve nem emme kapasiteleri $(4.00,47.16,21.30)$. DSC, $730^{\circ} \mathrm{C}^{\prime}$ de yüksek saflığı gösteren keskin bir tepe gösterdi. Her iki MCC de aynı organoleptik özellikleri, benzer DSC'yi gösterdi ve ayrıca zayıf akışkanlığa sahipti. Genel olarak, sonuçlar SO-MCC'nin fiziko-kimyasal özellikleri açısından ticari sınıf Avicel PH 102 ile olumlu bir şekilde karşılaştırıldığını ve mikrokristalin selüloz için İngiliz Farmakopesi spesifikasyonlarına uyduğunu gösterdi.

Anahtar Kelimeler: Saccharum officinarum, mikrokristal selüloz, fizikokimyasal özellikler, Avicel PH 102.

\section{Introduction}

An excipient must comply with pharmacopoeial and other official compendia requirements for its acceptability. Microcrystalline cellulose (MCC) has been derived from other sources [1] - [4] due to its outstanding merit and still remains the most used direct compression excipient serving as a strong dry binder, an adsorbent and anti-adherent [5]. MCC has also been widely used especially in food, cosmetic and medical industries as a water retainer, suspension stabilizer, flow characteristics controller in the systems used for final products, and as a reinforcing agent for final products such as medical tablets [6]. It has been reported that the properties of MCC obtained from different sources vary with respect to their crystallinity, porosity, bulk and tapped densities, morphology etc [7], [8].

Saccharum officinarum also known as sugarcane is an example of $6-37$ species of Saccharum (depending on taxonomic system) of tall perennial grasses (family: poaceae, tribe: Andropogeneae) which originated in New Guinea and is an important cultivated crop in the inland valleys of Nigeria [9]. The by-products from sugarcane (cane fibres), can be used to produce cellulosic ethanol, a second generation biofuel. Other sugarcane products include molasses, rum, and cachaca (a Brazilian alcohol), and the plant itself can be used as thatch and as livestock fodder [10]. The baggase/chips obtained from sugarcane stem may also because of its high cellulose content serve as raw material for pharmaceutical and food producing industries [11].

Previous studies on Saccharum officinarum has revealed the presence of microcrystalline cellulose from sugarcane [11], [12], [24]. As part of continuous efforts to develop local raw materials in order to increase our local content, we have in the present study obtained microcrystalline cellulose from the dried stem bark of Saccharum officinarum (sugarcane) and its physicochemical properties were compared with the commercial grade of microcrystalline cellulose, Avicel PH 102.

\section{Materials and Method}

\subsection{Materials}

The listed materials were used as purchased: N-hexane (Sigma Aldrich USA) Hydrochloric acid (JAD China),Sodium hydroxide (BDH England), Sodium hypochlorite (Jik Reckit and Colman Nig. Ltd.), distilled water (Lion water Nsukka), Avicel PH102 (Hiranya Cellulose Products, Telangana India). All other chemicals used were of analar grade. Sugarcane stem was gotten from Nsukka market, Enugu State of Nigeria. 


\subsection{Methods}

The matured stem bark of sugarcane was peeled off and the stems cut into bits of $2-4 \mathrm{~cm}$. These chips were pressed to remove the sap. It was air dried for 7days under ambient conditions; oven dried at $600 \mathrm{C}$ for $48 \mathrm{~h}$, milled into smaller chips using a Q-link blender (China) and weighed.

\subsubsection{Extraction of Alpha-Cellulose}

The experimental procedure adopted for extraction of microcrystalline cellulose in this study involved a slight modification of the method of Ohwoavworhua et al [3].

A $300 \mathrm{~g}$ quantity of dried Saccharum officinarum stem was placed in a stainless steel pot and $4 \mathrm{~L}$ of $2 \% \mathrm{w} / \mathrm{V}$ sodium hydroxide was added for digestion at $800 \mathrm{C}$ for $3 \mathrm{~h}$ using a heater (Binatone, ECP -120 (China). This removes lignin in the form of soluble complexes. It was then washed severally with distilled water and filtered. It was bleached with $10 \%$ aqeous dilution of sodium hypochlorite for $30 \mathrm{~min}$ at $1000 \mathrm{C}$, washed and then filtered. The washed and filtered material was further treated with $2 \mathrm{~L}$ of $17.5 \% \mathrm{w} / \mathrm{v}$ sodium hydroxide at $800 \mathrm{C}$ for $1 \mathrm{~h}$ and the resulting alpha cellulose was washed thoroughly with water and subjected to whitening process with $10 \%$ sodium hypochlorite for $15 \mathrm{~min}$ at $800 \mathrm{C}$, this was washed with water until neutral. The cellulose was filtered, processed and manually reduced to small pieces and dried at 600C with a hot air oven (Memmert Oven Schuttzart, Din 40050-1p20, W.Germany) for $1 \mathrm{~h}$.

\subsubsection{Preparation of Microcrystalline Cellulose (SO-MMC)}

A $50 \mathrm{~g}$ quantity of the alpha cellulose obtained was placed in $2 \mathrm{~L}$ flat bottom flask and hydrolyzed with $1 \mathrm{~L}$ of $2.5 \mathrm{~N}$ hydrochloric acid at $1000 \mathrm{C}$ for $15 \mathrm{~min}$. The acid mixture was poured into cold water which was followed by vigorous stirring with a glass rod. The microcrystalline cellulose obtained was washed with water until neutral, processed and dried in an oven at $650 \mathrm{C}$ for $1 \mathrm{~h}$ and stored in an airtight container under room temperature.

\subsection{Physicochemical Properties of SO-MCC}

\subsubsection{Chemical Identification of Microcrystalline Cellulose}

For chemical identification, the prepared powder SO-MCC $(10 \mathrm{mg})$ was dispersed in $2 \mathrm{ml}$ of iodinated zinc chloride solution in a petri dish and observed for colour reaction as specified in the BP [13].

\subsubsection{Organoleptic Properties}

A $10 \mathrm{~g}$ quantity of SO-MCC was weighed with the aid of a weighing balance. The organoleptic properties determined include taste, odour, colour and texture [13].

\subsection{3. pH Determination}

This was done by shaking $2 \mathrm{~g}$ of the powder material with $100 \mathrm{ml}$ of distilled water for $5 \mathrm{~min}$ and the $\mathrm{pH}$ of the supernatant liquid was determined using a $\mathrm{pH}$ meter (Hanna Instrument, Italy).

\subsubsection{Differential Scanning Calorimetry (DSC)}

DSC experiments were carried out to find out the presence of any impurities on the sample powder. SO-MCC was subjected to the study. 4,400mg was taken in the pierced DSC aluminum pan and scanned in the temperature range of 40 and $3000 \mathrm{C}$ at a scan rate of $5 \mathrm{k} / \mathrm{min}$. The heating rate was $100 \mathrm{C} / \mathrm{min}$; nitrogen served as purged gas and the system was cooled down by liquid nitrogen. DSC Star Excellence System Autosampler Metler- Toledo, Switzerland was used for this purpose and controlled by the software, STAR® SW13.00.

\subsubsection{Particle Size Analysis}

The particle size of the SO-MCC and Avicel PH 102 was determined using test sieves (numbers 16, 25, 52, 100 and 200) arranged in descending order of aperture size with a pan collector at the base. $25 \mathrm{~g}$ quantity of each powder was weighed using an electronic weighing balance (Ohaus Adventurer, China), and transferred to the top most range of sieves which was then transferred to an Endicott sieve shaker (Endicott's Ltd. UK) and shaken for $5 \mathrm{~min}$. The fraction of powder retained by each sieve was weighed. Three determinations were carried out and the mean particle diameter (dav) was calculated from the equation[14]. 


\subsubsection{True Density}

The true density of SO-MCC and Avicel ${ }^{\circledR}$ PH 102 were determined using a specific displacement pycnometer $(25 \mathrm{ml})$ filled with a non solvent (N-hexane). The true density was calculated using the equation

True Density $(T d)=\frac{\text { weight of powder }}{\text { True volume of powder }}$

\subsubsection{Bulk and Tapped Density}

A 25g quantity of SO-MCC powder and Avicel PH 102 was placed into a 100ml dry measuring cylinder and the volume occupied by the samples was noted as the bulk volume. The bulk density (Bd) was calculated using the formula [15] as shown in equation 3.

Bulk Density $(B d)=\frac{\text { Mass of the Powder }(M)}{\text { Bulk volume of powder }\left(V_{B}\right)}$

The cylinder was tapped on a wooden platform by dropping the cylinder from a height of one inch at 2 seconds intervals until there was no change in volume reduction. The volume occupied by the material was then recorded as the tapped volume. The tapped density was calculated using the formula:

Tapped Density $=\frac{\text { Mass of the powder }(M)}{\text { Tapped volume of powder }\left(V_{T}\right)}$

\subsubsection{Angle of Repose}

About $20 \mathrm{~g}$ of the SO-MCC powder was placed in a funnel of a fixed height of $7 \mathrm{~cm}$ and released to form a cone shaped heap. The height and diameter of the heap was recorded and angle of repose $(\theta)$ was calculated using the formula below[16]:

$\theta=\tan ^{-1} \frac{\text { Height of powder heap }}{\text { Radius of powder }}$

\subsubsection{Carr's Index and Hausner Ratio}

Carr's index was obtained using the formula

$C . I=\frac{\text { Tap density-Bulk density }}{\text { Tap density }} \times 100$

While Hausner's ratio was determined using the equation: 


\subsubsection{Powder Porosity}

This was gotten from the values of true and bulk densities when put into the equation:

$$
e=1-\frac{B d}{T d} x 100
$$

Where Bd is the bulk density, $\mathrm{Td}$ is the true density and e is the porosity

\subsubsection{Hydration Capacity}

The method used by Kornblum and Stoopak was adopted [17]. About 2.0g of SO-MCC was placed separately in four $15 \mathrm{ml}$ plastic centrifuge tubes and $10 \mathrm{ml}$ distilled water was added and stoppered. The contents were shaken for $3 \mathrm{~min}$, allowed to stand for 10min and immediately centrifuged using a Gallenkemp bench centrifuge (Gallenkemp, England) at 1000rpm for 10min. The supernatant was carefully decanted and sediment weighed. Hydration capacity was calculated using the formula:

$$
\text { Hydration capacity }(H C)=\frac{\text { Weight of sediment-Weight of tube }}{\text { Weight of dry sample }}
$$

\subsubsection{Swelling Capacity}

This was measured at the same time as the hydration capacity using the formula:

$$
S=\frac{\left(V_{2}-V_{1}\right)}{V_{1}} \times 100
$$

Where $\mathrm{S}$ is the \% swelling capacity, V2 is the volume of the hydrated or swollen material and V1 is the tapped volume of the material prior to hydration.

\subsubsection{Moisture Sorption Capacity}

A $2.0 \mathrm{~g}$ sample of SO-MCC was weighed accurately and distributed evenly over the surface of $70 \mathrm{~mm}$ tarred Petri dish, placed in a large desiccator with distilled water in its reservoir $(\mathrm{RH}=100 \%)$ at room temperature. The weight gained by the sample over a period of 5 days at various time intervals was noted and the amount of moisture absorbed was calculated from the weight difference [18].

\subsubsection{Statistical Analysis}

A $2.0 \mathrm{~g}$ sample of SO-MCC was weighed accurately and distributed evenly over the surface of $70 \mathrm{~mm}$ tarred Petri dish, placed in a large desiccator with distilled water in its reservoir $(\mathrm{RH}=100 \%)$ at room temperature. The weight gained by the sample over a period of 5 days at various time intervals was noted and the amount of moisture absorbed was calculated from the weight difference [18].

\section{Results and Discussion}

The percentage yield of microcrystalline cellulose from the starting material was $23 \% \mathrm{w} / \mathrm{w}$ and this compared well with $12.2 \% \mathrm{w} / \mathrm{w}$ yield obtained from the same plant as reported by [12].

The powder was subjected to iodinated zinc chloride solution which showed a violet blue colour in the presence of the reagent. This showed the powder as microcrystalline cellulose as stated in BP 2009 [13]. The microcrystalline cellulose prepared by treating the sugarcane stem with hydrochloric acid at $1000 \mathrm{C}$ was white, odourless, tasteless and coarse powder material. The $\mathrm{pH}$ test result showed that the SO-MCC produced has a $\mathrm{pH}$ of 7.5 while Avicel $\mathrm{PH} 102$ has 6.5. The BP specification for $\mathrm{pH}$ range for microcrystalline cellulose was between 


\section{Journal of Characterization}

5 to 7.5 , therefore, both the results of organoleptic and $\mathrm{pH}$ test complied with the stated specifications in the BP [13].

\begin{tabular}{l|c|c}
\multicolumn{3}{c}{ Table 1. Powders Properties of SO-MCC } \\
\hline Parameters & SO-MCC & Avicel PH102 \\
\hline$p H$ & 7.5 & 6.5 \\
\hline Particle Size $(\mu \mathrm{m})$ & $239 \pm 0.05$ & $242 \pm 0.05$ \\
\hline True density $(\mathrm{g} / \mathrm{ml})$ & $1.540 \pm 0.025$ & $1.521 \pm 0.040$ \\
\hline Bulk density $(\mathrm{g} / \mathrm{ml})$ & $0.464 \pm 0.040$ & $0.42 \pm 0.050$ \\
\hline Tapped density & $0.617 \pm 0.025$ & $0.625 \pm 0.025$ \\
\hline Angle of repose & $34.70 \pm 0.20$ & $33.40 \pm 0.15$ \\
\hline Hausner's quotient & 1.32 & 1.50 \\
\hline C.I & 25.00 & 33.00 \\
\hline Porosity $(\%)$ & 70.00 & 2.4 \\
\hline Hydration capacity & 4.00 & 24.50 \\
\hline Swelling capacity (\%) & 47.16 & 12.40 \\
\hline Moisture sorption capacity (\%) & 21.30 &
\end{tabular}

The Values in parenthesis represents standard deviation with $\mathrm{n}=3$

The DSC thermogram of SO-MCC (figure 1) was compared with reference to published data on Avicel PH 102 [19]. The thermogram of the standard showed glass transition at 73.30C while that of SO-MCC was 730C. The presence of a single major peak in the thermogram showed both samples has a high level of purity. Mazurek et al [20] had earlier reported the use of DSC to assess the purity of drug compounds.

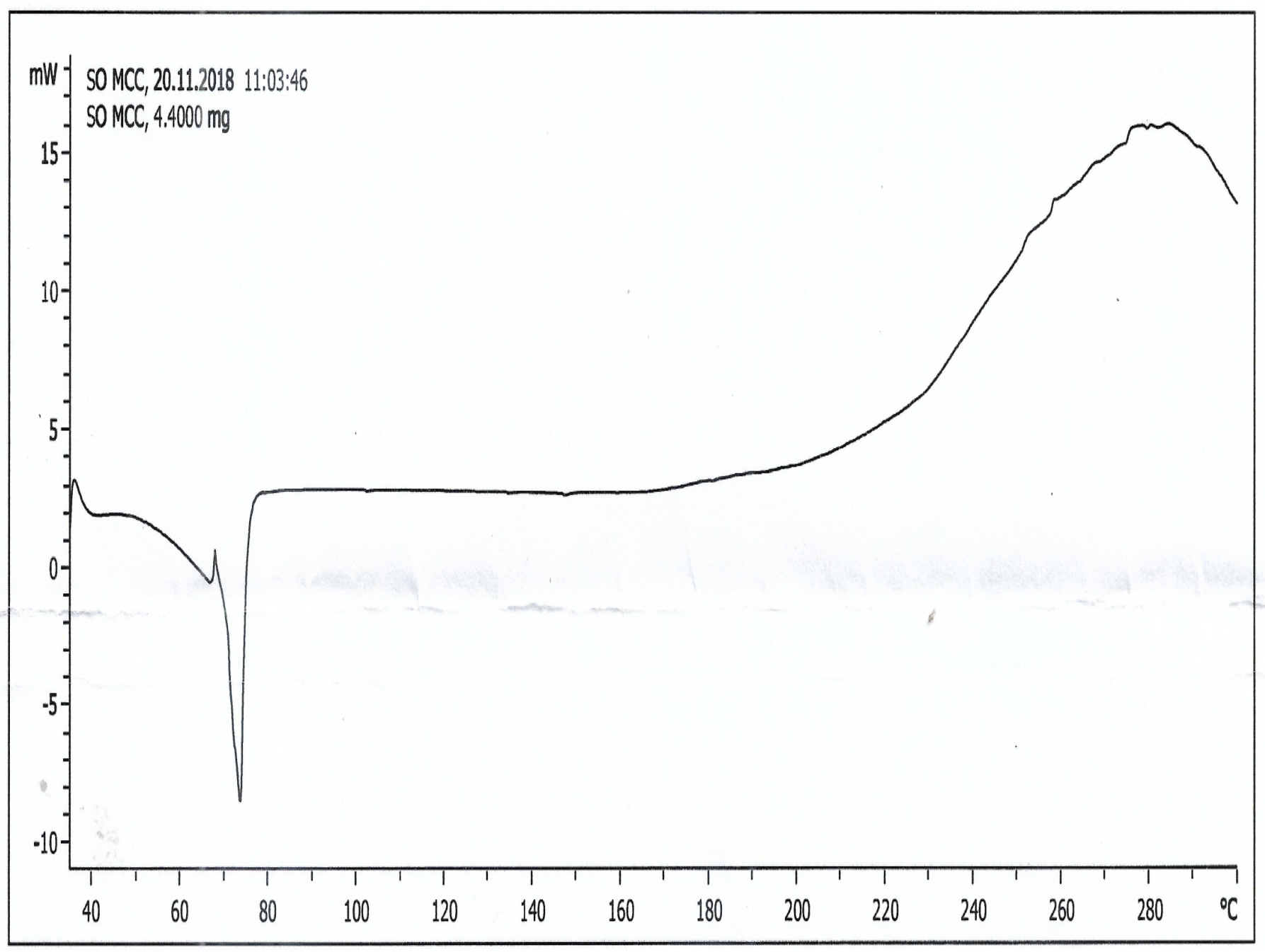

Figure 1. DSC Image of SO-MCC 


\section{Journal of Characterization}

The DSC thermogram of SO-MCC (figure 1) was compared with reference to published data on Avicel PH 102 [19]. The thermogram of the standard showed glass transition at 73.30C while that of SO-MCC was 730C. The presence of a single major peak in the thermogram showed both samples has a high level of purity. Mazurek et al [20] had earlier reported the use of DSC to assess the purity of drug compounds.

The particle size analysis of the SO-MCC produced from sugarcane stem and Avicel PH 102 showed that the SO-MCC exhibited mean particles diameter of $239.00 \pm 0.05 \mu \mathrm{m}$, while Avicel PH 102 has mean particle diameter of $242.00 \pm 0.05 \mu \mathrm{m}$. Aulton [21] had reported that particles larger than $250 \mu \mathrm{m}$ are usually relatively free flowing, but as the size falls below $100 \mu \mathrm{m}$, powders become cohesive which gives rise to flow problems. Also powders with particle size less than $10 \mu \mathrm{m}$ are usually extremely cohesive and resists flow under gravity, except as large agglomerates. The particles size of the SO-MCC and Avicel PH 102 showed that both had good properties to flow under gravity and could be used for direct compression tabletting and also as diluents and disintegrants in wet granulation.

The results of the true density of SO-MCC as shown in Table 1 showed that the difference between SO-MCC and Avicel PH 102 were not significant. The higher values of true density for SO-MCC compared to the Avicel PH 102 suggests that the SO-MCC might exhibit better compressibility [22].

The indirect method of assessment of flowability was used to ascertain the flow properties of SO-MCC [23].

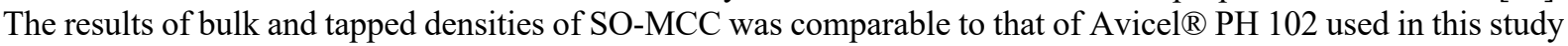
as reference. The bulk density of a powder is always less than the true density of its component particles because the powder contains interparticle voids or pores. A decrease in bulk density may bring about a reduction in particle size and produce a loose-packed powder bed which though porous, may not flow because of the inherent cohesions of the fine particles. The flow of powder during manufacturing shows the quality of the product in terms of content uniformity and weight of solid dosage forms [24].

The measurement of the flow properties of powders is important prior to tabletting and capsule filling because particle flow variation will give rise to capsule weight, tablet weight and active pharmaceutical ingredient variations. The flow property of bulk material results from the cohesive forces acting on individual particles such as electrostatic, surface tension, interlocking, friction and Van der Waals [25].

Angle of repose $\leq 30^{\circ}$ generally indicate a free flowing material. The results show SO-MCC and Avicel PH 102 had poor flow. Hausner's quotient determines the degree of interparticulate friction and values $>1.25$ indicates poor flow [26]. The results indicated that Hausner's quotient were above the range thus could result to poor flow. Also values from Carr's index below 16\% indicate good flowability while values above $35 \%$ indicate cohesiveness [26]. Thus, the flow indices (Table 1) showed that both SO-MCC and Avicel PH 102 flowed poorly. As a result, a glidant is needed when these materials are to be used in solid dosage formulation.

Swelling which is generally accepted as a measure of tablet disintegration ability can be evaluated by the determination of hydration capacity, swelling capacity and moisture sorption capacity [27]. The hydration capacity value of SO-MCC is higher than Avicel PH 102 (Table 1) which indicates that SO-MCC is capable of absorbing more than four times its own weight of water. The swellability which indicates increase in volume of the cellulose material after water uptake was $47.16 \%$ for SO- MCC and $24.50 \%$ for Avicel PH 102. This showed that only a small portion of absorbed water actually penetrated the individual cellulose particles causing them to swell. As a result, if this cellulose is incorporated in tablet formulation as disintegrants, the tablet will disintegrate by two mechanisms: wicking or capillary due to interparticulate water and swelling.

The moisture sorption capacity of SO-MCC as shown in Table 1 is higher than Avicel PH 102. Stamm [28] had reported that the crystalline portion of cellulose does not absorb water and that the extent of water adsorption by cellulose should be proportional to the amount of amorphous cellulose present.

The results suggest that SO-MCC would have higher proportion of amorphous cellulose than Avicel PH 102. Moreover, the study of moisture sorption capacity is essential since it shows the relative physical stability of tablets made from cellulose when stored under humid condition [5]. It can be depicted from the result that tablets produced using SO-MCC powder would be less stable when compared to that of Avicel PH 102. It further showed that cellulose powders are sensitive to atmospheric moisture and should be stored in an airtight container.

\section{Conclusions}




\section{Journal of Characterization}

Microcrystalline cellulose was successfully prepared from dried stem bark of Saccharum officinarum. The results of the physicochemical properties obtained complied with the standards for microcrystalline cellulose as specified in the British Pharmacopoeia for organoleptic, identification and $\mathrm{pH}$ tests. The differential scanning calorimetry of SO-MCC compared with Avicel PH 102 as earlier studied. The powder properties of SO-MCC revealed it had poor flow which could be improved by the use of glidants. Other test parameter results such as porosity, hydration capacity, moisture sorption capacity studies show that SO-MCC compared favourably with Avicel PH102. The swelling capacity indicate that SO-MCC would impart a better disintegrant action when compared to Avicel PH102 thus, could be explored as a disintegrant in the manufacture of pharmaceutical tablets.

\section{References}

[1] F.O. Ohwoavworhua, T.A. Adelakun, A.O. Okhamafe, "Processing pharmaceutical grade microcrystalline cellulose from groundnut husk: Extraction methods and characterization". International Journal of Green Pharmacy, vol. 3, no 2, pp.97 - 104, 2009.

[2] R.D. Roro, H.S. Sutriyo, "Preparation and characterization of microcrystalline cellulose produced from Betung Bamboo (Dendrocalamus asper) through Acid Hydrolysis". J. Young Pharm, vol. 10, no.2, pp. 578-583, 2018.

[3] F.O. Ohwoavworhua, S.I. Ofoefule, "Evaluation of the Disintegrant Properties of microcrystalline cellulose obtained from Luffa cylindrica in Aspirin-based formulations," African J. Pharm. Res. Dev. vol 2, no.1, pp. 5459,2006

[4] F.O. Ohwoavworhua, T.A. Adelakun, "Some physical characteristics of microcrystalline cellulose obtained from Raw cotton of Cochlospermum planchonii," Tropical Journal of Pharmaceutical research, vol. 4, no. 2; pp.501-507, 2005.

[5] O.N.C. Umeh, A.C. Nworah, S.I. Ofoefule. "Physicochemical properties of microcrystalline cellulose derived from Indian Bamboo (Bambusa vulgaris),” Int. J. Pharm. Sci. Rev. Res, vol. 29, no.2, pp.5-9, 2014.

[6] M.L. Hassan, M. El-Sakhawy, "Physical and mechanical properties of microcrystalline cellulose prepared from local Agricultural Residues", presented at 8th Arab International Conference on polymer science technology, Cairo, Egypt, 2005.

[7] D.K. Ranjan, N. Yuhka, E.O. Martins, K.B. Alak, "Extraction and characterization of microcrystalline cellulose from fodder grass; Setaria glauca (L) P. Beauv and its potential as a drug delivery vehicle for isoniazid, a first line antituberculosis drug," Colloids and Surface B: Biointerfaces vol. 108, pp. 85-89, 2013.

[8] M. Landin, R. Martinez Pacheco, A. Gomez, C. Souto, A. Conchero, R.C. Rowe, "Effect of batch variation and source of pulp on the properties of microcrystalline cellulose," Int. J. Pharm, vol. 91, pp. 133-141, 1993.

[9] L.D. Busari, S.M. Misari, G.O. Olaniyan, "Weed management systems in chewing cane production in the inland valleys of Nigeria," presented at 16th Biennial Conference of Weed Science Society of Eastern Africa, Kampala, Uganda, 1997.

[10] Y. Takeo, "Sugarcane," in Encylcopedia Britannica [Online document], 2019. Available: Britannica Reference Online, https://www.britannica.com/plant/sugarcane [Accessed: February 27, 2022].

[11] M. Adedokun, G. Essien, T. Uwah and C. Jackson, "Evaluation of the Release Properties of Microcrystalline cellulose derived from Saccharum officinarum L. in paracetamol Tablet formulation," Journal of Pharmaceutical Sciences and research, vol. 6, no. 10, pp. 342-346, 2014. 


\section{Journal of Characterization}

[12] N. Nwachuckwu, K.C. Ugoeze, "Studies on Microsrystalline Cellulose obtained from Saccharum officinarum: processing and Physicochemical properties," European Journal of biomedical and pharmaceutical sciences, vol. 5, no. 2, pp. 42-48, 2018.

[13] British Pharmacopoeia. The commission office London, vol. I and II, pp. 1694-1700, 2009.

[14] C.H. Ansel, G.N. Popovich and V.I. Allen, Ansel: Pharmaceutical Dosage forms and Drug Delivery Systems. Lippincott Williams and Wilkins, New York, 2005, pp.189.

[15] S.A. Chime, A.A. Attama, C.O. Agubata, J.D. Ogbonna and G.C. Onunkwo, "Micromeritic and antinoceptive properties of lyophilized indomethacin-loaded SLMs based on solidified reverse micellar solution,"J. Pharm. Res., vol. 5, no. 6, pp. 3410-3416, 2012.

[16] D. Train, "Some aspects of the property of angle of repose of powders, J. Pharm. Pharmacology, vol. 10, pp. 127-134, 1958.

[17] S.S. Kornblum and S.B. Stoopak, "A new tablet disintegrant agent crosslinked polyvinylpyrollidone,"J. Pharm. Sci. vol. 62, no. 1, pp. 43-49, 1973.

[18] J.D. Audu-Peter, J.E. Ojile, P.G. Bhatia, "Physicochemical and powder properties of alpha and microcrystalline cellulose derived from maize cobs," J. Pharm. Biores, vol. 1, no. 4, pp. 1-45, 2004.

[19] A.M. Mohammed and E.J. Al-Akkam, "Formulation and evaluation of clopidogrel liquisolid compact," Iraqi Journal of pharmaceutical sciences, vol. 27, no. 2, pp. 135-149, 2018.

[20] W.E. Mazurek, K. Winnieka, K.A. Czajkowska, U. Czyzewska, W. Miltyk, "Application of differential scanning calorimetry in evaluation of solid state interactions in tablets containing acetaminophen," Acta Pol. Pharma. Vol. 70, no. 5, pp. 787-793, 2013.

[21] M.E. Aulton, "Pharmaceutics: The Science of Dosage form Design,"3rd Edition, Churchill Livingstone, Edinburgh: 2007, pp-198-210.

[22] C.P. Azubuike, B.O. Silva, A.O. Okhamafe, "Pharmacopoeial and physicochemical properties of -cellulose and microcrystalline cellulose powders derived from cornstalks", International Journal of Green Pharmacy, vol. 6, no.1, pp. 93-98, 2012.

[23] J.N. Staniforth, "Powder flow," in Pharmaceutics, M. Aulton. The science of Dosage form Design, Churchill Livingstone: 1996, pp-600-615.

[24] I.V. Onyishi, S.A. Chime, C.A. Okoroji, "physicochemical properties of microcrystalline cellulose from Saccharum officinarum: Comparative Evaluation with Avicel PH101," American Journal of Pharm. Tech Research, vol. 3, no. 5, pp. 415-426, 2013.

[25] L. Lachman, A. Herbert and J. Lieberman, "The theory and practice of Industrial Pharmacy" Mumbai: 1990, pp-318-320.

[26] J.N. Oraeluno, J.C. Obasi, E.A. Bamigbola, B.A. Joseph, "Production and Evaluation of Disintegrant Properties of microcrystalline cellulose derived from Saccharum officinarum L (Poaceae) in metronidazole based formulation,” International Journal of Pharmaceutical Science and Medicine, vol. 6, no. 4, pp. 42-51, 2021.

[27] C.Caramela, "Novel methods for disintegrants characterization," part 1, Pharm. Technol, pp. 48-55, 1991.

[28] A.F. Stamm, Wood and Cellulose Science. New York: The Ronald Press, 1964. 